\title{
Faktor Sosiodemografi yang Memengaruhi Pemilihan Metode Kontrasepsi
}

\author{
Asti Dewi Rahayu Fitrianingsih, Soenarnatalina Melaniani \\ Departemen Biostatistika dan Kependudukan \\ Fakultas Kesehatan Masyarakat Universitas Airlangga \\ Alamat Korespondensi: \\ Asti Dewi Rahayu Fitrianingsih \\ Email: fitriamidwife7@gmail.com
}

\begin{abstract}
Long term contraception entered into government programs. Government suggested to use long term contraception effectively to postponing pregnancy, spacing of birth and terminating fertility. In fact, couples of reproductive ages in Indonesia were likely to still choose short-term contraceptive than long-term contraceptive. This research analyzed sosiodemografi factors that affecting the selection of contraception method in Gading Public Health Center Tambaksari Surabaya. This research used analytical study with case control design. Research population totaled 84 respondents. Sampling technique used simple random sampling and got 42 cases and 42 controls. The variables were sosiodemografi factors. Data were analyzed using that multivariate logistic regression with a level of significance value $\alpha=0,05$. The results showed four significant variables were age $(p=0,018)$, education $(p=0,024)$, occupation $(p=0,008)$, parity $(p=0,034)$, also status of women $(p=0,002$. Sosiodemografi factors such as age, occupation, parity and status women affect the injection contraceptive acceptors did not choose long acting contraception method in Tambaksari Surabaya Gading Public Health Center. The granting of complete information about all types of contraception is important so that the fertile age couples can choose contraception that suits their need.
\end{abstract}

Keywords: family planning, long-term contraceptive

\begin{abstract}
ABSTRAK
Program penggunaan metode alat kontrasepsi jangka panjang sudah masuk dalam program pemerintah. Pemerintah menganjurkan penggunaan alat kontrasepsi MKJP karena lebih efektif dalam menunda kehamilan, mengatur jarak kelahiran dan menghentikan kesuburan. Namun, pasangan usia subur (PUS) di Indonesia cenderung memilih non MKJP dibandingkan MKJP. Tujuan dalam penelitian ini adalah untuk menganalisis faktor sosiodemografi yang memengaruhi pemilihan alat kontrasepsi di Puskesmas Gading Kecamatan Tambaksari, Surabaya. Penelitian ini merupakan penelitian observasional dengan menggunakan case control study. Populasi penelitian berjumlah 84 responden. Pengambilan sampel dengan simple random sampling dan didapatkan sampel sebanyak 42 orang sebagai kasus dan 42 orang sebagai kontrol. Variabel yang diteliti yaitu faktor sosiodemografi. Data dianalisis menggunakan teknik regresi logistik multivariat dengan nilai signifikan $\alpha=0,05$. Hasil uji regresi didapatkan empat faktor sosiodemografi yang signifikan yaitu umur $(p=0,018)$, pekerjaan $(p=0,008)$, paritas $(p=0,034)$, serta status wanita $(p=0,002)$. Faktor sosiodemografi yaitu umur, pekerjaan paritas dan status wanita memengaruhi pemilihan alat kontrasepsi di Puskesmas Gading Kecamatan Tambaksari, Surabaya. Pemberian informasi secara lengkap mengenai semua jenis kontrasepsi penting dilakukan sehingga pasangan usia subur (PUS) dapat memilih alat kontrasepsi yang sesuai dengan kebutuhannya.
\end{abstract}

Kata kunci: keluarga berencana, metode kontrasepsi jangka panjang

\section{PENDAHULUAN}

Indonesia merupakan negara dengan jumlah penduduk terbanyak keempat di dunia. Jumlah penduduk yang terus meningkat akan menimbulkan masalah kependudukan (Manuaba, et al., 2010). Jumlah penduduk Indonesia tahun 2014 adalah sebanyak 252.164,8 ribu jiwa, terdiri dari 125.715,2 laki-laki dan 125.449,6 perempuan. Tahun 2010-2014 laju pertumbuhan penduduk yaitu sekitar $1,40 \%$ per tahun (BPS, 2014). Laju pertumbuhan yang tinggi berpengaruh terhadap kesejahteraan dan tingkat kehidupan penduduk (BKKBN, 2012).

Menurut BKKBN (2011), jenis kontrasepsi berdasarkan lama efektivitasnya dibagi dua, yaitu MKJP dan non MKJP. Kebijakan program 
KB pemerintah saat ini lebih mengarah pada penggunaan kontrasepsi MKJP (IUD, Implant, MOW dan MOP). Pemerintah lebih menganjurkan MKJP berdasarkan pertimbangan non MKJP tidak ekonomis dan efisien dibandingkan MKJP (BKKBN, 2012).

MKJP lebih efisien dibandingkan non MKJP dalam ketersediaan anggaran dan penyediaan kontrasepsi serta lebih efektif karena tingkat efek samping, komplikasi dan tingkat kegagalan lebih rendah (BKKBN, 2012). Winner B, et al (2012), menyebutkan dengan menggunakan MKJP selain akan menghemat biaya pengeluaran seseorang tidak perlu sering berkunjung untuk memperoleh alat kontrasepsi kembali serta cepat mengembalikan kesuburan.

MKJP memiliki tingkat efektifitas lebih tinggi, namun setiap tahun jumlah akseptor non MKJP di Indonesia selalu mengalami peningkatan dibandingkan dengan MKJP (IUD, Implant, MOW dan MOP) yang cenderung menurun. Hal ini dapat terlihat dari target yang ditetapkan pada PPM tahun 2014 yang hanya mencapai 51,59\% (BKKBN, 2014). Penurunan jumlah akseptor MKJP disebabkan pola kecenderungan pemakaian kontrasepsi di Indonesia yang umumnya masih terarah pada non MKJP (BKKBN, 2013). Akseptor non MKJP di Indonesia tahun 2013 yaitu sebanyak $83,79 \%$ dan pada tahun 2014 meningkat menjadi $88,04 \%$ sedangkan jumlah akseptor non MKJP mengalami penurunan yaitu sebanyak $16,21 \%$ pada tahun 2013 menjadi 11,96\% tahun 2014 (BKKBN, 2014)

Hasil sensus penduduk Indonesia tahun 2010 Provinsi Jawa Timur merupakan provinsi kedua dengan jumlah penduduk terbanyak di Indonesia setelah Jawa Barat (BPS, 2010). PUS di Jawa Timur masih cenderung memilih non MKJP. Sebanyak 86,78\% akseptor KB baru di Jawa Timur tahun 2013 memilih Non MKJP dan meningkat menjadi 89,41\% pada tahun 2014. Berbeda dengan akseptor MKJP yang mengalami penurunan yaitu sebanyak $13,22 \%$ pada tahun 2013 menjadi 10,59\% tahun 2014 (BKKBN, 2014).

Pencapaian peserta KB baru non MKJP di Surabaya tahun 2014 sebanyak 82,57\%, sedangkan pengguna Non MKJP dan MKJP 17,43\% (BKKBN, 2014). Kecamatan Tambaksari setiap tahunnya merupakan kecamatan dengan jumlah peserta KB aktif non MKJP terbanyak di kota Surabaya. KB non MKJP terutama mengalami peningkatan pada tahun 2012 sebanyak $48,13 \%$ menjadi $52,03 \%$ pada tahun 2013 (BPS, 2013).

Kecamatan Tambaksari memiliki tiga puskesmas yaitu Puskesmas Pacar Keling, Puskesmas Gading dan Puskesmas Rangkah. Data hasil pelayanan KB dari ketiga Puskesmas tahun 2014 menunjukkan bahwa Puskesmas Gading memiliki jumlah akseptor non MKJP tertinggi.

Penggunaan kontrasepsi dipengaruhi faktor sosiodemografi (umur, pendidikan, pekerjaan, paritas, jumlah keinginan mempunyai anak dan status wanita), faktor lingkungan (keluarga, masyarakat, petugas), faktor program (pengetahuan tentang $\mathrm{KB}$, pengalaman menggunakan KB sebelumnya, informed consent, Informed choice) dan faktor sarana (ketersediaan obat atau alat kontrasepsi, tenaga pelayanan, tempat pelayanan dan biaya (Asih dan Oesman, 2009).

Faktor sosiodemografi dapat menyebabkan pemakaian MKJP terutama di kalangan wanita yang pernah kawin di Indonesia masih rendah. Hasil mini survey peserta KB aktif, dan hasil studi tentang kualitas pelayanan KB mengungkapkan bahwa banyak wanita menggunakan kontrasepsi dengan tidak rasional (tidak sesuai dengan umur ibu dan jumlah anak yang diinginkan). Banyak pasangan yang masih memakai kontrasepsi non MKJP tetapi sudah tidak ingin memiliki anak lagi atau ingin menunda kehamilan lebih dari 2 tahun, fenomena ini merupakan hal yang tidak efisien, sehingga perlu dikaji lebih lanjut (BKKBN, 2011).

Variabel terkuat yang memengaruhi pemilihan alat kontrasepsi adalah umur. Umur memengaruhi jumlah anak yang dimiliki dan keinginan untuk mempunyai anak. Semakin tua umur seseorang maka akan semakin bijak dalam memilih alat kontrasepsi. Wanita yang berumur kurang dari 30 tahun berpeluang lebih besar untuk tidak menggunakan MKJP. Status wanita juga memengaruhi pemilihan alat kontrasepsi. Status atau peran wanita yang dimaksud adalah keterlibatan wanita dalam mengambil keputusan memilih kontrasepsi. Wanita yang terlibat dalam 
mengambil keputusan dalam memilih kontrasepsi cenderung akan menggunakan MKJP (Asih dan Oesman, 2009)

\section{METODE}

Rancang bangun penelitian merupakan observasional dan bersifat analitik dengan tujuan menganalisis pengaruh variabel yang diteliti. Penelitian menggunakan pendekatan case control study. Jumlah populasi penelitian 84 pasangan usia subur (PUS) yang terbagi menjadi 2 kelompok yaitu, 42 responden PUS sebagai kelompok kasus yaitu wanita usia subur usia (15-49 tahun) yang menggunakan non MKJP dan 42 PUS sebagai kelompok kontrol yaitu pasangan usia subur (15-49 tahun) yang menggunakan metode kontrasepsi jangka panjang (MKJP). Pengambilan sampel menggunakan simple random sampling.

Penelitian dilakukan di wilayah Puskesmas Gading Kecamatan Tambaksari Kota Surabaya,
Jawa Timur. Pengumpulan data dilakukan pada bulan November-Desember 2015.

Sumber data penelitian diperoleh melalui data primer dan sekunder. Instrumen pengumpulan data primer menggunakan kuesioner sebagai panduan proses wawancara yang sebelumnya responden telah diberi penjelasan dan telah menandatangani pernyataan persetujuan mengikuti penelitian. Kuesioner digunakan untuk mengetahui faktor sosiodemografi responden yaitu umur, pendidikan, pekerjaan, paritas, jumlah anak yang diinginkan dan status wanita. Data sekunder didapatkan dari Buku Evaluasi Pelaksanaan Program Keluarga Berencana BKKBN tahun 2013 sampai dengan tahun 2014 dan buku laporan pelayanan KB puskesmas yang berada di Puskesmas Kecamatan Tambaksari tahun 2014.

Variabel dependen penelitian adalah pemilihan metode kontrasepsi yaitu MKJP dan Non MKJP dan variabel independen penelitian yaitu faktor sosiodemografi (umur, pendidikan,

Tabel 1. Faktor Sosiodemografi Responden, Puskesmas Gading, 2015

\begin{tabular}{|c|c|c|c|c|c|c|c|}
\hline \multirow{2}{*}{ Faktor Sosiodemografi } & \multicolumn{2}{|c|}{ MKJP } & \multicolumn{2}{|c|}{ Non MKJP } & \multicolumn{2}{|c|}{ Total } & \multirow{2}{*}{$\mathbf{P}$} \\
\hline & $\mathbf{N}$ & $\%$ & $\mathbf{N}$ & $\%$ & $\mathbf{N}$ & $\%$ & \\
\hline \multicolumn{8}{|l|}{ Umur(tahun) } \\
\hline$<30$ & 11 & 30,6 & 25 & 69,4 & 36 & 100,0 & \multirow{2}{*}{0,042} \\
\hline$\geq 30$ & 31 & 64,8 & 17 & 35,4 & 48 & 100,0 & \\
\hline \multicolumn{8}{|l|}{ Pendidikan } \\
\hline Rendah (SD, SMP) & 18 & 38,3 & 29 & 61,7 & 47 & 100,0 & \multirow{2}{*}{0,474} \\
\hline Tinggi (SMA, Perguruan Tinggi) & 24 & 64,9 & 13 & 35,1 & 37 & 100,0 & \\
\hline \multicolumn{8}{|l|}{ Pekerjaan } \\
\hline Ya & 20 & 40,8 & 29 & 59,2 & 49 & 100,0 & \multirow{2}{*}{0,025} \\
\hline Tidak & 22 & 62,9 & 13 & 37,1 & 35 & 100,0 & \\
\hline \multicolumn{8}{|l|}{ Paritas (jumlah anak) } \\
\hline$<3$ anak & 22 & 37,3 & 37 & 61,7 & 59 & 100,0 & \multirow{2}{*}{0,027} \\
\hline$\geq 3$ anak & 20 & 80,0 & 5 & 20,0 & 25 & 100,0 & \\
\hline \multicolumn{8}{|l|}{ Jumlah anak yang diinginkan } \\
\hline$<3$ anak & 35 & 47,3 & 39 & 52,7 & 74 & 100,0 & \multirow{2}{*}{0,891} \\
\hline$\geq 3$ anak & 7 & 70,0 & 3 & 30,0 & 10 & 100,0 & \\
\hline \multicolumn{8}{|l|}{ Status Wanita } \\
\hline Ya & 39 & 59,1 & 27 & 40,9 & 66 & 100,0 & \multirow{2}{*}{0,000} \\
\hline Tidak & 3 & 16,7 & 15 & 83,3 & 18 & 100,0 & \\
\hline
\end{tabular}


pekerjaan, paritas, jumlah anak yang diinginkan dan status wanita). Data yang terkumpul kemudian dianalisis menggunakan uji regresi logistik.

\section{HASIL}

Faktor individu yang diteliti pada penelitian ini adalah umur, pendidikan, pekerjaan, paritas, jumlah anak yang diinginkan dan status wanita. Hasil analisis menunjukkan dari variabel faktor sosiodemografi yang diteliti sebagian besar memberikan pengaruh $(p<0,05)$, hanya dua variabel yaitu pendidikan dan jumlah anak yang diinginkan yang tidak memengaruhi pemilihan metode kontrasepsi di Puskesmas Gading Kecamatan Tambaksari Surabaya.

\section{Umur}

Variabel umur menunjukkan dari 36 PUS yang berusia kurang dari 30 tahun, sebagian besar adalah kelompok PUS yang menggunakan Non MKJP yaitu 69,4\% dibandingkan kelompok PUS yang menggunakan MKJP yaitu 30,6\%. Uji regresi logistik menunjukkan tingkat signifikansi umur $0,042(\alpha=0,05)$, yang artinya umur memengaruhi pemilihan alat kontrasepsi di Puskesmas Gading Kecamatan Tambaksari Surabaya.

\section{Pendidikan}

Hasil tabulasi silang variabel pendidikan menunjukkan dari 37 PUS yang berpendidikan tinggi (SMA, Perguruan Tinggi) sebagian besar merupakan kelompok PUS pengguna MKJP yaitu 64,9\% dibandingkan kelompok PUS pengguna Non MKJP yaitu 35,1\%. Hasil uji regresi logistik diperoleh tingkat signifikansi tingkat pendidikan $0.474(\alpha=0,05)$, yang artinya pendidikan tidak berpengaruh terhadap pemilihan alat kontrasepsi di Puskesmas Gading Kecamatan Tambaksari Surabaya.

\section{Pekerjaan}

Variabel pekerjaan menunjukkan dari 35 PUS pengguna yang tidak bekerja sebagian besar adalah kelompok PUS pengguna MKJP yaitu $62,9 \%$, dibandingkan PUS pengguna Non MKJP yaitu 37,1\%. Uji regresi logistik menunjukkan tingkat signifikansi status pekerjaan $0,025(\alpha=0,05)$, yang artinya pekerjaan memengaruhi pemilihan metode kontrasepsi di Puskesmas Gading Kecamatan Tambaksari Surabaya terhadap status pekerjaan.

\section{Paritas (jumlah anak)}

Variabel paritas (jumlah anak) menunjukkan bahwa dari 25 PUS yang memiliki anak lahir hidup yang memiliki jumlah anak lebih dari tiga sebagian besar adalah kelompok PUS pengguna MKJP yaitu 80,0\%, dibandingkan dengan PUS pengguna Non MKJP yaitu 20\%. Uji regresi logistik menunjukkan tingkat signifikansi anak lahir hidup $0,027(\alpha=0,05)$, yang artinya paritas (jumlah anak) memengaruhi pemilihan metode kontrasepsi di Puskesmas Gading Kecamatan Tambaksari Surabaya terhadap anak lahir hidup dan anak masih hidup.

\section{Jumlah anak yang diinginkan}

Variabel jumlah anak yang diinginkan menunjukkan bahwa dari 10 orang PUS yang ingin memiliki anak lebih dari 3 sebagian besar merupakan kelompok PUS pengguna MKJP yaitu $70 \%$ dibandingkan dengan PUS pengguna Non MKJP 30,0\% uji regresi logistik menunjukkan tingkat signifikansi jumlah anak yang diinginkan $0,891(\alpha=0,05)$. Nilai signifikansi tersebut lebih dari taraf nyata $(\alpha=0,05)$ yang artinya jumlah keinginan mempunyai anak tidak memengaruhi pemilihan metode kontrasepsi di Puskesmas Gading Kecamatan Tambaksari Surabaya.

Tabel 2. Faktor Sosiodemografi yang Memengaruhi Pemilihan Metode Kontrasepsi, Puskesmas Gading, 2014.

\begin{tabular}{lcccc}
\hline Variabel & $\mathbf{B}$ & $\mathbf{P}$ & $\mathbf{O R}$ & $\mathbf{9 5 \%} \mathbf{C I}$ \\
\hline Umur (tahun) & 1,269 & 0,018 & 0,281 & $0,099-$ \\
& & & & 0,801 \\
Pekerjaan & 1,178 & 0,008 & 3,247 & $1,356-$ \\
& & & & 7,772 \\
Paritas & 1,431 & 0,034 & 0,239 & $0,063-$ \\
(jumlah anak) & & & & 0,900 \\
Status Wanita & 2,375 & 0,002 & 10,755 & $2,385-$ \\
& & & & 48,490 \\
\hline
\end{tabular}




\section{Status wanita}

Variabel status wanita menunjukkan bahwa dari 18 PUS, sebagian besar kelompok PUS pengguna non MKJP tidak memiliki wewenang dalam mengambil keputusan dalam keluarga yaitu 83,3\% dibandingkan PUS pengguna MKJP yaitu $16,7 \%$. Hasil uji regresi logistik diperoleh tingkat signifikansi umur 0,000 ( $\alpha=0,05)$, yang artinya wewenang wanita memengaruhi pemilihan metode kontrasepsi di Puskesmas Gading Kecamatan Tambaksari Surabaya terhadap status wanita.

Seluruh variabel yang berpengaruh kemudian dilakukan uji regresi logistik multivariat untuk mengetahui pengaruh dan interaksi antar variabel dengan pemilihan alat kontrasepsi menggunakan uji regresi logistik multivariat.

Hasil uji regresi logistik multivariat menunjukkan faktor sosiodemografi yang paling memengaruhi pemilihan metode kontrasepsi di Puskesmas Gading Kecamatan Tambaksari Surabaya yaitu umur, pekerjaan, paritas (jumlah anak) dan status wanita. Keempat variabel memiliki nilai $p$ yang lebih kecil dibandingkan nilai $\alpha=0,05$.

Umur memiliki nilai $p 0,018$ yang artinya PUS yang berumur kurang dari 30 tahun memiliki risiko 0,281 kali tidak akan menggunakan MKJP dibandingkan PUS yang berumur 30 tahun atau lebih. Pekerjaan memiliki nilai $p 0,008$, yang artinya PUS yang bekerja memiliki risiko 3,247 kali tidak akan memilih MKJP dibandingkan PUS yang tidak bekerja.

Paritas memiliki nilai $p$ 0,034 yang artinya PUS yang memiliki anak kurang dari tiga memiliki risiko 0,239 tidak akan memilih MKJP dibandingkan PUS yang sudah memiliki tiga anak atau lebih. Status wanita memiliki nilai $p 0,002$ yang artinya wanita yang tidak memiliki wewenang dalam mengambil keputusan di keluarga memiliki risiko 10,755 tidak akan memilih MKJP dibandingkan wanita yang memiliki wewenang di keluarganya.

\section{PEMBAHASAN}

\section{Umur}

Tindakan menyelamatkan ibu dan anak akibat melahirkan pada usia muda atau terlalu tua, jarak kelahiran yang terlalu dekat dan terlalu sering melahirkan perlu dilakukan untuk menciptakan keluarga yang berkualitas. Sebagian besar PUS dikelompok non MKJP berumur kurang dari 30 tahun, sedangkan PUS pengguna MKJP sebagian besar berumur lebih dari 30 tahun. Uji regresi logistik multivariat menunjukkan variabel umur memengaruhi pemilihan metode kontrasepsi di Puskesmas Gading Kecamatan Tambaksari Surabaya. PUS yang berumur kurang dari 30 tahun memiliki risiko tidak akan memilih MKJP 0,281 kali lebih besar dibandingkan responden yang berumur lebih dari 30 tahun.

Menurut Hartanto (2010), seseorang yang semakin tua akan semakin bijaksana dan matang dalam memilih kontrasepsi. Sistem hormonal, struktur organ serta fungsi faal seseorang dipengaruhi oleh umur, sehingga kebutuhan dalam memilih metode kontrasepsi yang aman dan efektif (Kusumaningrum, 2009).

Yusuf (2001), menyatakan bahwa kecenderungan 8 kali lebih besar untuk menggunakan MKJP dimiliki oleh ibu yang berumur tua ( $>30$ tahun) dibandingkan dengan ibu yang berumur muda. Penelitian sependapat dengan penelitian Asih dan Oesman (2009) yang mengemukakan bahwa sebagian besar pemakaian kontrasepsi MKJP umumnya digunakan oleh wanita berumur 30 tahun atau lebih (relatif tua), sementara peserta KB non MKJP umumnya digunakan wanita berumur kurang dari 30 tahun (relatif muda).

Periode mengandung dan melahirkan paling baik adalah pada usia di bawah umur 30 tahun, sehingga metode kontrasepsi yang dianjurkan adalah kontrasepsi yang mempunyai efektivitas tinggi dan dapat mengembalikan kesuburan dengan cepat karena masih ada harapan untuk melahirkan dan mempunyai anak lagi. Umur di atas 30 tahun dan telah mempunyai 2 orang anak, sebaiknya mengakhiri kehamilan. Pilihan utama alat kontrasepsi pada usia lebih dari 30 tahun adalah alat kontrasepsi mantap misalnya MOW atau MOP karena kontrasepsi ini dapat dipakai untuk jangka panjang dan tidak menambah kelainan yang biasanya meningkat pada usia tua seperti penyakit jantung, darah tinggi dan gangguan metabolisme (Hartoyo, 2011). 
Notoatmodjo (2010) mengatakan perilaku seseorang termasuk dalam pemilihan alat kontrasepsi dipengaruhi oleh umur. Peluang lebih kecil untuk menggunakan metode MKJP dimiliki oleh wanita usia muda dibandingkan dengan yang tua.

\section{Pendidikan}

Tingkat pendidikan adalah pendidikan formal yang pernah ditamatkan oleh seseorang. Hasil analisis regresi logistik multivariat menunjukkan pendidikan tidak memengaruhi pemilihan metode kontrasepsi di Puskesmas Gading Kecamatan Tambaksari Surabaya.

Hasil penelitian berlawanan dengan pendapat Koentjaraningrat (1991), yang mengatakan informasi baru akan lebih mudah diterima pada seseorang yang memiliki tingkat pendidikan tinggi yang menyebabkan tingkat pengetahuan ikut meningkat. Tingkat pendidikan yang tinggi akan memudahkan pengguna KB menerima informasi sehingga semakin banyak pula pengetahuan tentang berbagai macam alat kontrasepsi MJKP maupun Non MKJP. Keikutsertaan dalam ber-KB termasuk dalam pemilihan metode kontrasepsi dipengaruhi oleh tingkat pendidikan (Handayani, 2010).

\section{Pekerjaan}

Kelompok PUS pengguna Non MKJP sebagian besar bekerja berbeda dengan kelompok PUS pengguna MKJP yang sebagian besar tidak bekerja. Hasil analisis regresi logistik multivariat menunjukkan pekerjaan memengaruhi pemilihan metode kontrasepsi di Puskesmas Gading Kecamatan Tambaksari Surabaya. PUS yang bekerja memiliki risiko tidak akan memilih MKJP 3,247 kali lebih besar dibandingkan PUS yang tidak bekerja.

Pekerjaan memengaruhi wanita dalam menggunakan MKJP (PHAA, 2013). Affandi (2011), mengatakan bahwa wanita yang memiliki pekerjaan yang melibatkan aktivitas fisik yang tinggi seperti bersepeda, mengangkat barang, berjalan, naik turun tangga atau sejenisnya, kemungkinan tidak akan menggunakan MKJP seperti IUD dan implant dengan alasan takut lepas (ekspulsi), dan khawatir akan mengganggu pekerjaan atau menimbulkan nyeri saat bekerja.

\section{Paritas (jumlah anak)}

Jumlah anak yang dimiliki PUS di kelompok non MKJP sebagian besar berjumlah kurang 1-2 anak, sedangkan kelompok MKJP sebagian besar memiliki 3 anak atau lebih. Uji regresi logistik multivariat menunjukkan paritas memengaruhi pemilihan metode kontrasepsi di Puskesmas Gading Kecamatan Tambaksari Surabaya. PUS yang memiliki anak kurang dari 3 memiliki risiko tidak akan memilih MKJP 0,239 yang memiliki lebih dari atau sama dengan 3 anak.

Penelitian Yusuf (2001), menunjukkan peluang 7,5 kali lebih tinggi untuk memilih non MKJP dimiliki oleh PUS yang mempunyai anak kurang dari 3 dibandingkan dengan PUS yang memiliki anak lebih dari 3. Ibu primipara (anak pertama) umumnya ibu usia muda yang belum mempunyai pengalaman dalam hal pemilihan alat kontrasepsi dibandingkan dengan ibu multipara untuk memilih alat kontrasepsi karena pengalaman sebelumnya (Notoatmodjo, 2010). Pemilihan metode kontrasepsi umumnya sulit dilakukan oleh ibu usia muda dan primipara (anak pertama) dibandingkan dengan ibu mutipara yang sebagian besar memiliki pengalaman dalam pemilihan alat kontrasepsi. Seorang wanita akan memiliki pengalaman dan pengetahuan kontrasepsi berdasarkan jumlah anak yang dimiliki (Fienalia, 2012).

Purwoko (2000), mengatakan pada saat memilih kontrasepsi pasangan usia subur akan dipengaruhi oleh jumlah anak yang dimiliki. Pasangan usia subur yang memiliki jumlah anak hidup sedikit cenderung menggunakan Non MKJP yang efektivitas rendah, sedangkan pada pasangan dengan jumlah anak banyak terdapat kecenderungan menggunakan MKJP yang efektivitasnya tinggi.

Kecenderungan untuk menghentikan kesuburan dimiliki oleh ibu yang memiliki jumlah anak banyak sehingga cenderung memilih alat kontrasepsi mantap (Yanuar, 2010). Frost dan Darroch (2008) mengatakan PUS yang telah memiliki banyak anak sebagian besar memilih sterilisasi.

MKJP dapat mengurangi dan mencegah risiko kematian maternal terutama pada ibu yang memiliki jumlah anak lebih dari tiga. 
Pasangan suami istri yang memiliki anak banyak memiliki lebih besar kemungkinan untuk memulai kontrasepsi dibandingkan dengan pasangan yang mempunyai anak lebih sedikit. Keluarga akan mulai memperhatikan jumlah anak karena jumlah anak akan menjadi tanggungan kepala keluarga dalam mencukupi kebutuhan materiil dan menjaga kesehatan sistem reproduksi karena semakin sering melahirkan kesehatan ibu akan semakin rentan (Wiknjojosastro, 2005).

\section{Jumlah keinginan mempunyai anak}

Penelitian menunjukkan tidak ada pengaruh variabel jumlah keinginan mempunyai anak tidak memengaruhi pemilihan metode kontrasepsi di Puskesmas Gading Kecamatan Tambaksari Surabaya. Hasil penelitian tidak sesuai dengan teori Bulatao danRonald (1983), yang mengatakan bahwa kebutuhan akan anak memengaruhi metode KB yang digunakan. Keinginan dalam memiliki anak akan membentuk suatu permintaan yang tidak memperhitungkan baik pasokan atau kemungkinan keterbatasan biaya keluarga. Ukuran keluarga utama pada pasangan mungkin memiliki preferensi mengenai jenis kelamin anak, jarak kelahiran dan pendidikan anak. Kebutuhan dapat ditentukan oleh interaksi antara keinginan terhadap anak dan kendala terhadap pasangan, terlepas dari keterbatasan pasokan dan biaya dalam mengatur kesuburan. Bulatao dan Ronald (1983), mengasumsikan bahwa preferensi antara anak sama dengan barang, termasuk seperti barang konsumen dan kegiatan rekreasi.

\section{Status Wanita}

Status wanita merupakan keterlibatan/ wewenang wanita dalam pengambilan keputusan di keluarga. Status wanita dapat dilihat diantaranya dari aspek banyaknya peran serta wanita dalam pengambilan keputusan memilih alat kontrasepsi untuk dirinya (Asih dan Oesman, 2009).

Status wanita pada PUS di kelompok pengguna MKJP lebih besar dibandingkan dengan kelompok PUS pengguna Non MKJP. Hasil regresi logistik multivariat menunjukkan variabel status wanita memengaruhi pemilihan alat kontrasepsi. Ibu yang tidak memiliki status wanita di dalam keluarganya memiliki risiko tidak akan memilih MKJP 10,755 kali lebih besar dibandingkan PUS yang memiliki status wanita di dalam keluarganya.

Asih dan Oesman (2009) mengatakan peran wanita dalam mengambil keputusan berpengaruh terhadap pemakaian kontrasepsi MKJP. Keterlibatan wanita dalam memilih alat kontrasepsi untuk dirinya sendiri banyak ditemukan terutama pada ibu yang merasa sudah memiliki banyak anak dan memutuskan untuk menghentikan kehamilan sehingga ibu akan lebih memilih MKJP.

Status wanita, yaitu di mana wanita mempunyai peran serta dalam pengambilan keputusan. Tampak bahwa wanita yang menggunakan MKJP mempunyai status wanita lebih besar dibandingkan dengan non MKJP. Beberapa studi menunjukkan semakin banyak peran wanita dengan ikut serta dalam pengambilan keputusan tampak bahwa wanita ini bisa mengambil keputusan dengan lebih mandiri, termasuk dalam memilih kontrasepsi (Asih dan Oesman, 2009).

Rendahnya status wanita pada pengguna Non MKJP menunjukkan rendahnya kewenangan wanita dalam menentukan alat kontrasepsi untuk dirinya sendiri, faktor yang dapat menyebabkan rendahnya status wanita diantaranya adalah peranan pasangan dalam keluarga. Dukungan suami sangat berpengaruh dalam pengambilan keputusan menggunakan atau tidak metode kontrasepsi yang akan dipakai, tanpa dukungan suami, hanya sedikit istri yang berani untuk tetap menggunakan alat kontrasepsi (Harymawan, 2007). Gudaynhe, et al (2014), mengungkapkan wanita yang telah mendiskusikan kontrasepsi dengan suaminya cenderung akan memilih MKJP.

Wiknojosastro (2005), mengatakan masih banyak ditemukan suami yang melarang istrinya menggunakan MKJP terutama IUD karena beranggapan bahwa IUD mengurangi kenikmatan hubungan seksual. Kontrasepsi tidak dipakai oleh istri tanpa kerjasama suami dan saling percaya (Hartanto, 2010). 


\section{SIMPULAN DAN SARAN}

\section{Simpulan}

Faktor sosiodemografi yang memengaruhi pemilihan alat kontrasepsi di Puskesmas Gading adalah umur $(p=0,018$; OR $=0,281$; CI: 0,099 $0,801)$, pekerjaan $(p=0,008 ; \mathrm{OR}=3,247$; CI: $1,356-7,772)$, paritas $(p=0,034 ; \mathrm{OR}=0,239$; CI: $0,063-0,900)$ dan status wanita $(p=0,002$; $\mathrm{OR}=10,755$; CI: 2,385-48,490).

\section{Saran}

Tenaga kesehatan seperti bidan dan dokter sebaiknya berperan aktif memotivasi PUS yang telah memiliki dua anak masih hidup berusia relatif muda (kurang dari 30 tahun) dan berusia tua (lebih dari 30 tahun) yang telah memiliki 2 anak masih hidup atau lebih untuk segera menggunakan MKJP. Pentingnya melakukan kerja sama antara tokoh masyarakat (PLKB, Kader, PKK, guru) dan petugas puskesmas dalam pemberian informasi secara lengkap kepada PUS mengenai segala kelemahan dan efek samping dari semua jenis kontrasepsi.

\section{DAFTAR PUSTAKA}

Affandi, B. 2011. Buku Panduan Praktis Pelayanan Kontrasepsi Edisi 3. Jakarta: YBP-SP.

Asih dan Oesman. 2009. Analisa Lanjut SDKI 2007. Faktor Yang Memengaruhi Pemakaian Kontrasepsi Jangka Panjang (MKJP). Jakarta: Puslitbang KB dan Kesehatan Reproduksi Badan Koordinasi Keluarga Berencana Nasional.

BKKBN. 2011. Analisis Lanjut 2011. Faktor Yang Memengaruhi Penggunaan MKJP di Enam Wilayah Indonesia. Jakarta: Pusat Penelitian dan Pengembangan KB dan Keluarga Berencana Nasional Tahun 2011.

BKKBN. 2012. Evaluasi Pelaksanaan Program Keluarga Berencana Nasional. Materi Rakernas Program KB Nasional tahun 2009, Jakarta: BKKBN

BKKBN. 2012. Informasi Pelayanan Kontrasepsi. Jakarta: BKKBN.

BKKBN. 2014. BKKBN bina Akseptor KB Untuk Gunakan MKJP. http://rri.co.id/surabaya/post/ berita/76325/kesehatan/bkkbn_bina_akseptor_ kb_untuk_digunakan_mkjp.html (sitasi 25 Maret 2015).

BKKBN. 2014. Evaluasi Hasil Pelaksanaan Program. Surabaya: Perwakilan BKKBN Provinsi Jawa Timur.

BPS. 2010. Statistik Indonesia Tahun 2010. Jakarta Pusat: Badan Pusat Statistika

BPS. 2013. Surabaya Dalam Angka 2013. Surabaya: Badan Pusat Statistika Kota Surabaya

BPS. 2014. Data Kependudukan Indonesia tahun 2014. Jakarta: Badan Pusat Statistika.

Bulatao, R.A.dan Ronald,L.D. 1983. Determinants of Fertility in Developing Countries Volume 1. Supply and Demand for Children. New York: Academic Press.

Fienalia, R. 2012. Faktor yang Berhubungan dengan Penggunaan Metode Kontrasepsi Jangka Panjang di Wilayah Kerja Puskesmas Pancoran Mas Depok. Jurnal FKM UI, 3 (6)

Fitrianingsih, Asti Dewi R.F. 2016 Faktor Penyebab Akseptor KB Suntik Tidak Memilih Metode Kontrasepsi Jangka Panjang (MKJP) di Kecamatan Tambaksari Surabaya). Skripsi. Surabaya: Fakultas Kesehatan Masyarakat Universitas Airlangga.

Frost, J. J. dan Darroch, E. J., 2008. Factors Associated with Contraceptive Choice and Inconsistent Method Use. Perspectives on Sexual and Reproductive Health, 40(2).

Gudaynhe,S. W., Zegeye, D. T., Asmamaw, T. \& Kibret, G. D. 2014. Factors Affecting the use of Long-Acting Reversible Contraceptive Method among Married Women in Debre Markos Town, Northwest Ethiopia 2013. Global Journal og Medical Reasearch: E Gynecology and Obstetrics, 14(5).

Handayani, S. 2010. Pelayanan Keluarga Berencana. Yogyakarta: Pustaka Rihama.

Hartanto. 2010. Keluarga Berencana dan Kontrasepsi. Jakarta: Pustaka Sinar Harapan.

Hartoyo. 2011. Studi Nilai Anak, Jumlah Anak yang Diinginkan dan Keikutsertaan Orang Tua dalam Program KB. Jurnal Ilmiah Keluarga dan Konsultasi, Volume 4 (1).

Harymawan. 2007. Peran Dukungan Sosial dan Kesehatan Keluarga. Bandung: Remaja Rosda Karya. 
Koentjaraningrat. 1991. Metode Penelitian Masyarakat. Jakarta: Universitas Indonesia

Kusumaningrum. 2009. Faktor-Faktor yang Memengaruhi Pemilihan Jenis Kontrasepsi yang Digunakan pada Pasangan Usia. Skripsi. Semarang: Universitas Diponegoro.

Notoatmodjo. 2010. Ilmu Perilaku Kesehatan. Jakarta: Rineka Cipta.

PHAA. 2013. Time For A Change: Increasing The Use of Long Acting Reversible. Sexual Health \& Family Planning Australia, 1(1).

Purwoko. 2000. Penerimaan Vasektomi dan Sterilisasi Tuba. Tesis. Semarang: Fakultas Kedokteran Universitas Diponegoro.
Wiknojosastro, G. 2005. Panduan Praktis Pelayanan Kontrasepsi. Jakarta: YBP-SP.

Winner B, et al. 2012. Effectiveness of LongActing Reversible Contraception. The New England Journal of Medicine, 366(21).

Yanuar. 2010. Pengaruh Pengetahuan dan Sikap perternakan Pasangan Usia Subur tentang KB terhadap Pemilihan Kontrasepsi di Lingkungan Keluarga Joho Kecamatan Sukoharjo. Skripsi. Yogyakarta: UGM.

Yusuf. 2001. Faktor-Faktor yang Berhubungan dengan Pemakaian MKJP di Tanjung Batu Kabupaten Ogan Kampung Ilir Sumatera Selatan Tahun 2000. Skripsi. Depok: FKM UI 